\title{
Decoupling $\mathrm{CO}_{2}$ Emissions in Nordic countries: Panel Data Analysis
}

\author{
https://doi.org/10.21272/sec.3(2).15-30.2019
}

\section{Debesh Bhowmik}

$\mathrm{PhD}$, Retired Principal and Associated with The Indian Econometric Society, India

\begin{abstract}
The paper summarizes the principal notions of Kuznets hypothesis and Environmental Kuznets Curve as well as their implications in Nordic countries as examined by eminent scholars. The survey of huge literatures on this issue indicated that the absolute and relative decoupling of $\mathrm{CO}_{2}$ emissions were quite relevant for those countries who have been playing leading role in combating emissions to fulfill Paris Agreement. The main purpose of the research is to test empirically the decoupling $\mathrm{CO}_{2}$ emissions per capita from the GDP per capita in the Nordic countries from the World Bank data during 1970-2016 through panel data analysis which can detect the feasibility of environmental Kuznets curve hypothesis. This verification might be relevant to achieve higher GDP per capita that could force $\mathrm{CO}_{2}$ emission per capita to decline after a threshold point. The paper applied simple semi-log linear trend model to compute growth rate of GDP per capita and $\mathrm{CO}_{2}$ emission per capita. Fixed effect panel regression model was used after verifying Hausman test (1978) to find out decoupling theory. Bai-Perron model (2003) was applied for structural breaks of $\mathrm{CO}_{2}$ emission per capita. Fisher (1932) and Johansen model $(1988,1991)$ were used to find panel cointegration and vector error correction. The Wald test (1943) was done to confirm short run causality of the variables. The Cointegrating equations were justified to sort out long run causalities. Unit circle and impulse response functions showed stability and non- stationary of the model. The empirical findings of the time series data from 1970-2016 proved that Denmark and Norway satisfied the decoupling hypothesis significantly but Finland, Greenland, Iceland, Sweden showed insignificant decoupling. Denmark, Iceland and Sweden have downward structural breaks of $\mathrm{CO}_{2}$ emissions per capita and Norway showed upward structural breaks. On the other hand fixed effect panel regression analysis verified that there is no decoupling from per capita GDP , but there is absolute decoupling from square of the per capita GDP and there is relative decoupling from cube of the per capita GDP of the Nordic Countries from 1970 to 2016.Cointegration test suggest that both $\mathrm{CO}_{2}$ emission per capita and GDP per capita are cointegrated and VECM and the Wald test confirmed that there is short run and long run causalities from GDP per capita to $\mathrm{CO}_{2}$ emission per capita.The empirical research verified that environment Kuznets curve hypothesis is feasible in the Nordic countries during 1970-2016 and its shape is inverse $\mathrm{U}$ shaped. The results of the research can be useful to formulate policies on targeting GDP growth rate to reduce $\mathrm{CO}_{2}$ emissions within a specified period in the Nordic region.
\end{abstract}

Keywords: $\mathrm{CO}_{2}$ emissions per capita, GDP per capita, decoupling $\mathrm{CO}_{2}$ emissions, panel cointegration, Vector Error Correction, climate policy of Nordic countries, short run causality, long run causality.

JEL Classification: C14, C23, C32, Q01, Q38, Q43, Q52, Q53, Q5.

Cite as: Bhowmik, D. (2019). Decoupling CO2 Emissions in Nordic countries: Panel Data Analysis. SocioEconomic Challenges, 3(2), 15-30.https://doi.org/10.21272/sec.3(2).15-30.2019.

(C) The Author, 2019. This article is published with open access at Sumy State University.

\section{Introduction}

There are two basic forms of decoupling: absolute and relative decoupling. Relative decoupling of resources or impacts means that the growth rate of the environmentally relevant parameter ( e.g. greenhouse gas emission ) is lower than the growth rate of a relevant economic indicator (for example GDP). The association is still positive, but the elasticity of this relation is below 1. In absolute decoupling, in contrast, greenhouse gas emissions decline, irrespective of the growth rate of the economic driver -GDP. If their elasticity is greater than one then there will no decoupling. But a strong decoupling occurs when the GDP increases and GHG emissions decrease while their elasticity is below zero. A weak decoupling appears when GDP and GHG 
emissions both increase but GDP grows faster than the GHG emissions. Again a recessive decoupling occurs when both GDP and GHG emissions decrease but emissions decrease more rapidly than the GDP.

Kuznets (1955) hypothesized that economic inequality initially increases, reaches a critical threshold and then decreases as the country developed. The Kuznets Curve hypothesis (1955) was extended to the Environmental Kuznets Curve that claims that if prosperity rises beyond a certain point, the environmental impact of production and consumption decreases. This fundamental notion was first developed by Gross and Krueger (1991,1995).In 1991,the authors estimated simple cubic function of the levels of income per capita with ambient pollution levels in many cities around the world and found that the concentrations of various pollutants peaked when a country reached roughly the level of Mexico's per capita income at the time. In 1995, the authors studied per capita environmental degradation level by way of a polynomial equation of per capita income. They examined reduced form relationship between national GDP and various indicators of local environmental conditions using panel data from the Global Environmental Monitoring System taking 14 kinds of environmental indicators such as $\mathrm{SO}_{2}$, smoke, heavy particles etc. and estimated random effect model in 52 cities of 32 countries during 1977-1988. In most of the indicators economic growth brings an initial phase of deterioration followed by a subsequent phase of improvement. The estimated curve is inverse $\mathrm{U}$ shaped although turning points for different pollutants vary but in most of the cases they reach a certain point of per capita income.

In the EKC hypothesis it is assumed that environmental degradation increases with per capita income during the early stages of economic growth, and then declines with per capita income after passing beyond an income turning point (Stern, 2004).Hence, the relationship between economic development and environmental degradation resembles an inverted U-shaped curve.

Moreover, York (2012) observed that carbon emission increased faster with economic growth than they fell in recessions but Burke et al.(2015) concluded that there is no strong evidence that the emissions income elasticity is larger during the period of economic expansion as compared to recession.

In the Nordic countries decoupling of greenhouse gas emissions from the economic growth was observed in the Figure 1 where emissions declines while GDP increases which can satisfy the Environmental Kuznets Curve.

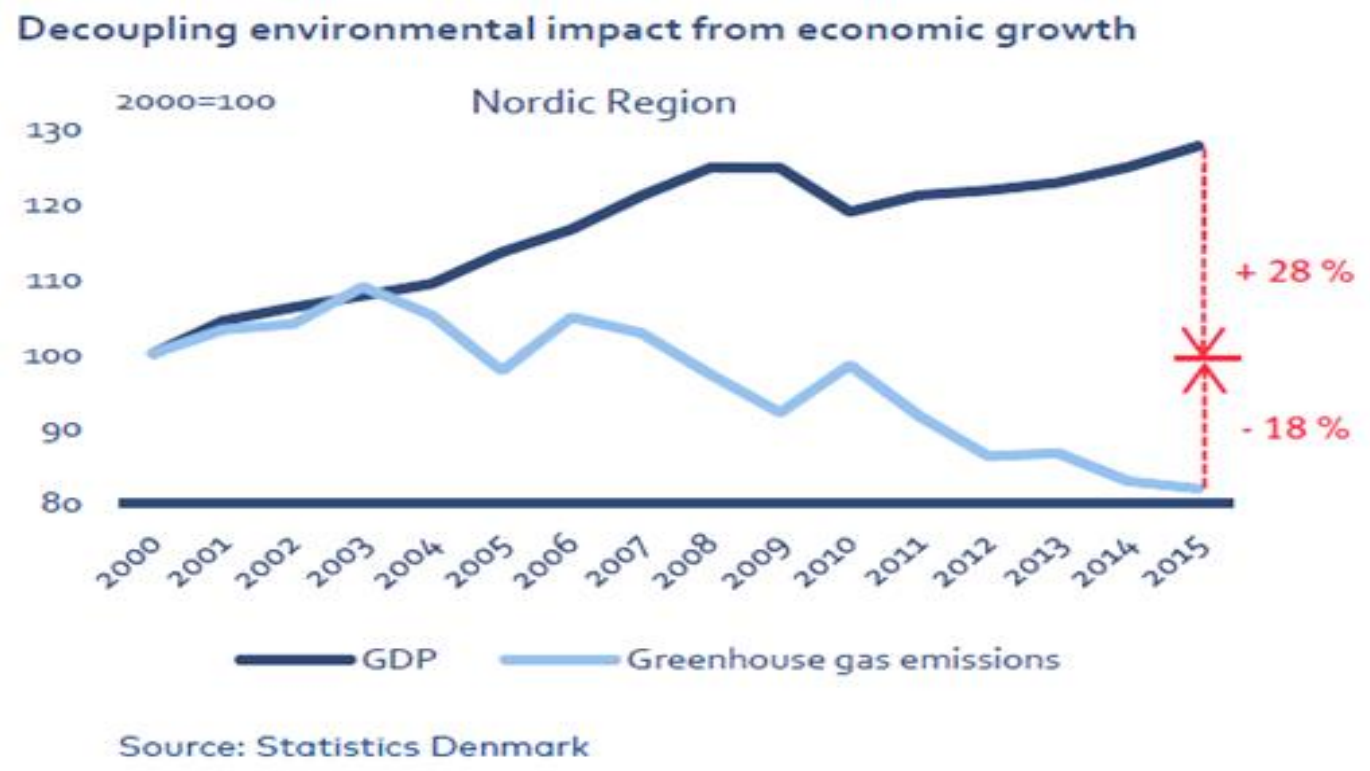

Figure 1. Decoupling GHG emissions from GDP in Nordic countries

From the global perspective, the Nordic countries' achievements to date as well as challenging road towards a carbon-neutral future are significant. All five Nordic countries have actively used policy frameworks in decoupling $\mathrm{CO}_{2}$ emissions from GDP.They are 25 years ahead of the rest of the world since they committed to be carbon neutral in electricity production within 2050.Nordic countries are working with IEA to reduce Nordic Energy Related $\mathrm{CO}_{2}$ by $85 \%$ in 2020 compared to 1990 levels which is consistent with the target of Nordic governments and are allied with the Paris Agreement. In July,2016, IEA Executive Director Fatih 
Birol said that the Nordic region is a leader in clean energy and offers examples of policies and technologies needed in a global response to the Paris Agreement.

Nordic countries speed up the transition to a sustainable low-carbon society.They proved how sustainable development is possible with strong climate policies contributing to economic growth and employment generation as well as environmental improvements. They successfully showed how ambitious climate mitigation targets and policies can be combined with high levels of human development. Nordic countries aim to achieve a reduction of emission by $40 \%$ within 2030 compared to 1990 .This target is fully consistent with the recent IPCC report which mentioned that if the countries are willing to keep up global warming at $1.5^{\circ} \mathrm{C}$ then all should reduce $\mathrm{CO}_{2}$ emissions by $45 \%$ within 2050 compared to 2010 level.They are working actively to ensure swift and full implementation of the Paris Agreement cooperating with UNFCCC and international climate policy forums.They are pioneered in energy and carbon taxes and switched to renewable sources.Nordic citizens are well aware of the related environmental issues and municipalities are widely striving to promote green energy by setting their own targets and launching local initiatives.The most remarkable feature is that Nordic countries started negative- $\mathrm{CO}_{2}$ project funded by Nordic Energy Research. On May,2018, the event Sustainable Future Energy Systems:Smarter,integrated and $\mathrm{CO}_{2}-$ Negative brought to the new vision for Nordic Energy Systems, which will give them chance of reaching climate and energy goals.

\section{Some important literatures}

Miljoverndepertementel(1991) showed the Norwegian climate change assessment which was based on scenarios derived from $2 \mathrm{xCO}_{2}$ GCM model which was assumed to apply around 2020 to 2050.The model predicted most probable temperature increase of 1.5 to $3.5^{\circ} \mathrm{C}$ and a precipitation increase of 5 to $15 \%$ depending on location and season. Alexandersson and Dahlstrom (1992) defined a climate change scenario for Sweden around 2030 which specified a warming of 0.0 to $1.5^{\circ} \mathrm{C}$ and an increase in precipitation of 0 to $10 \%$ depending on location and season compared to 1990 values. Fenger and Torp(1992) assessed the climate change of Denmark which suggested temperature increase of $3.5 \pm 1.5^{\circ} \mathrm{C}$ (Winter) and $2.0 \pm 1.0^{\circ} \mathrm{C}$ (Summer) and a precipitation increase of 10 to $15 \%$ in 2080.Carter(1992) estimated the climate change scenario of Finland for evaluating potential economic and social impacts . This estimate showed a warming rate of $0.4{ }^{\circ} \mathrm{C}$ per decade and a precipitation increase of $3 \%$ per decade in winter but no precipitation increase in summer. Aittoniemi (1992) defined three scenarios for 2025 for Finland and Iceland and predicted temperature increase in the range 1.5 to $6.0^{\circ} \mathrm{C}$ (winter) and 0.8 to $3.0^{\circ} \mathrm{C}$ (summer) and precipitation increase between 10 to $35 \%$.But the best estimate was suggested by the experts at the workshop for Nordic climate which showed that mean annual temperature will increase by $3^{\circ} \mathrm{C}$ with the range of 2 to $5^{\circ} \mathrm{C}$ by 2100 and is less warming in North Atlantic than Finnish at east west gradient.

Lin and Li (2011) mentioned that Denmark, Finland, Sweden, Netherlands and Norway were the first adapters of carbon tax. Introducing the difference-in-difference method, the authors indicated that the carbon tax in Finland imposed a significant and negative impact on growth of its per capita $\mathrm{CO}_{2}$ emissions, while in Denmark, Sweden and Netherlands are negative but not significant. In Norway, carbon tax actually has not realized to mitigation effects as the rapid growth of energy products drives a substantial increase of $\mathrm{CO}_{2}$ emissions in oil drilling and natural gas exploitation sectors. Atici (2011) examined the trade liberalization and environment interaction in Japan and ASEAN using extended Environmental Kuznets Curve with panel data during 1960-2006 and found that carbon emissions have inverted S shape with trade liberalization when EKC is examined. It indicated that the level of per capita carbon emission will decrease when the level of GDP increase. Using SVAR and IRF in USA, Denmark, Spain and Portugal during 1960-2004, Silva, Soares and Pinho(2012) showed the impact of renewable energy on economic growth and $\mathrm{CO}_{2}$ emission. It was found that an increase in renewable energy sources -economic growth share may initially harm economic growth except for USA but contribute to the $\mathrm{CO}_{2}$ emission reduction in Denmark, Portugal and Spain. Kulionis(2013) used VAR and Granger causality models in Denmark during 1972-2012 and found that there is no significant causality between the economic growth and renewable energy consumption which implies that energy conservation policies should not have significant impact on economic growth. Also it showed that there is no causality between economic growth and $\mathrm{CO}_{2}$ emission in Denmark. Mazzanti and Musolesi (2014) applied GAMM and ARMA models during 1960-2001 in North America, Oceania, South and North Europe to find out long term carbon emission-income relationship and observed that there is threshold effect on $\mathrm{CO}_{2}$ development relation in Denmark, Sweden and Finland while for all other countries this relation appears to be monotonic and positive. Fei, Rasiah and Shen (2014) used autoregressive distributed lag model in New 
Zealand and Norway during 1971-2010 which indicated that there is a long run equilibrium among clean energy, economic growth, $\mathrm{CO}_{2}$ emissions and technological innovation. The Granger Causality suggests that the use of clean energy does usages $\mathrm{CO}_{2}$ emissions at the expense of economic growth. Andersson(2015) also claimed that carbon tax was effective in reducing $\mathrm{CO}_{2}$ emissions in Sweden during 1990-2005 where 10.9\% reduction of emission was observed which was equivalent to 2.5 million metric tons of $\mathrm{CO}_{2}$. Kasperowicz(2015)applied ECM, panel unit root tests, panel cointegration test and EGLS estimator in 18EU countries (including Denmark, Finland, Sweden) during 1995-2012 and concluded that the long run relationship between GDP and $\mathrm{CO}_{2}$ emissions is negative while the short run relationship between GDP and $\mathrm{Co}_{2}$ emissions is positive. The economic growth and $\mathrm{Co}_{2}$ emissions are cointegrated for the panel countries. Handrich, Kemfert, Mattes, Pavel and Traber(2015) examined in US, China, India, Malaysia, EU and Non-EU OECD countries during 1990-2014 with panel cointegration, Engel and Granger causality and ECM methodology and found that there is weak decoupling over last 5 years for all countries and strong decoupling over last decade in OECD and weak decoupling in USA ,India and China. There is bi-directional impact between renewable conventional energy and GDP indicating a feed-back relationship. Using VAR and Granger Causality Test, Irandoust (2016) showed that there is unidirectional causality running from renewable energy to $\mathrm{CO}_{2}$ emissions for Denmark and Finland and a bi-directional causality between these variables for Sweden and Norway. The results indicate that there is a unidirectional causality running from technological innovation to renewable energy and from growth to renewable energy for the four Nordic countries. The results could not confirm any causality from renewable energy to growth. Zhao (2016) verified empirically the EKC in Sweden, Denmark, Norway and Finland during 1961-2010 taking $\mathrm{CO}_{2}$ as proxy of environmental degradation where fixed effect model on panel data showed that those countries growth and emission pattern are rather ambiguous and there is no clear support of the EKC theory. Obradovic and Lojanica(2017) studied that there is long run causality from energy and $\mathrm{CO}_{2}$ emissions to economic growth in Sweden and Bulgaria during 1980-2010 which was derived from vector error correction model. In the short run there is no causality between energy and economic growth in both the countries. Urban and Nordensvard (2018) found out that the Nordic countries were the leaders in low carbon energy transitions and showed that EKC has been observed in Denmark, Iceland and Sweden during 1960-2015 but not in Norway and Finland. For per capita emissions, EKC is visible in Denmark, Finland, Iceland and Sweden but not in Norway. For energy use per capita, the EKC is only observed in Denmark. The decoupling of economic growth from carbon emissions has been observed particularly for Sweden, Denmark and Iceland which proved that low carbon energy transitions are possible while maintaining economic growth and high levels of human well- being.

\section{Objective of the paper}

In this paper, the author examined the long run association between the $\mathrm{CO}_{2}$ emission per capita and GDP per capita of the Nordic countries during 1970-2016 .The paper verified the Environmental Kuznets Curve hypothesis between the two variables and proved the decoupling $\mathrm{CO}_{2}$ emissions per capita from the GDP per capita of the Nordic countries using panel data analysis in applying fixed effect regression, cointegration and panel vector error correction models. The paper also tested the individual countries' decoupling hypothesis during 1970-2016 through time series data and found structural shifts of the emissions per capita. The results of the models were justified from the climate policies of the Nordic countries.

\section{Source of data and Methodology}

The data of $\mathrm{CO}_{2}$ emissions per capita in metric tons and GDP per capita in US\$ of the Nordic countries from 1970-2016 have been collected from the World Bank. The paper applied simple semi-log linear trend model to compute growth rate of GDP per capita and $\mathrm{CO}_{2}$ emission per capita. The Fixed Effect Panel Regression model is applied after rejection of the Hausman test (1978). The Bai-Perron (2003) model is used to show the structural breaks of $\mathrm{CO}_{2}$ emissions. The Fisher(1932)-Johansen(1988) panel cointegration test is applied to verify long run association. Johansen model $(1988,1991)$ of panel VECM showed error corrections and long run causalities. To verify short run causality the Wald test (1943) is used. The Cointegrating equations were justified to sort out long run causalities. Unit circle and impulse response functions showed stability and nonstationary of the model.

\section{Major findings of the models}

In Denmark, the hypothesis of Environmental Kuznets Curve satisfied as have been seen from the following estimated regression equations. 
$\log \left(\mathrm{y}_{1}\right)=86.5989-27.2483 \log \left(\mathrm{x}_{1}\right)+2.932785 \log \left(\mathrm{x}_{1}\right)^{2}-0.10497 \log \left(\mathrm{x}_{1}\right)^{3}$

$$
(2.91)^{*}(-2.935)^{*} \quad(3.050)^{*} \quad(-3.175)^{*}
$$

$\mathrm{R}^{2}=0.678, \mathrm{~F}=28.89^{*}, \mathrm{DW}=0.707, *=$ significant at $5 \%$ level , $\mathrm{y}_{1}=\mathrm{co}_{2}$ emission per capita(metric tons) of Denmark, $\mathrm{x}_{1}=$ GDP per capita (US\$) of Denmark. Emission is absolute decoupled with per capita GDP and cube of per capita GDP $\left(\delta \log _{1} / \delta \log x_{1}\right.$ and $\delta \log _{1} / \delta \log \left(\mathrm{x}_{1}\right)^{3}$ are less than zero)but there is no decoupling with square of per capita GDP of Denmark $\left(\delta \log y_{1} / \delta \log \left(\mathrm{x}_{1}\right)^{2}\right.$ is greater than one).Therefore, Kuznets hypothesis revisits.

In Finland, no hypothesis of Environmental Kuznets Curve is satisfied which was verified by the following estimated equation.

$\log \left(\mathrm{y}_{2}\right)=15.74817-4.828179 \log \left(\mathrm{x}_{2}\right)+0.564469 \log \left(\mathrm{x}_{2}\right)^{2}-0.021526 \log \left(\mathrm{x}_{2}\right)^{3}$
$(0.73)$
$(-0.69)$
(0.76)
$(-0.827)$

$\mathrm{R}^{2}=0.16, \mathrm{~F}=2.74, \mathrm{DW}=0.7709, *=$ significant at $5 \%$ level, $\mathrm{y}_{2}=\mathrm{co}_{2}$ emission per capita in metric tons in Finland, $\mathrm{x}_{2}=$ GDP per capita in US\$ of Finland.

There is absolute decoupling from GDP per capita and cube of GDP per capita $\left(\delta \log _{2} / \delta \log _{2}\right.$ and $\delta \log _{2} / \delta \log \left(\mathrm{x}_{2}\right)^{3}$ are less than zero) and there is relative decoupling from square of GDP per capita of Finland $\left(\delta \log _{2} / \delta \log \left(\mathrm{x}_{2}\right)^{2}\right.$ is less than one) but all coefficients are insignificant.

In Greenland, the insignificant decoupling $\mathrm{CO}_{2}$ emissions from GDP per capita was observed from the estimated equation.

$$
\log \left(\mathrm{y}_{3}\right)=-10.72041+4.68545 \log \left(\mathrm{x}_{3}\right)-0.5565 \log \left(\mathrm{x}_{3}\right)^{2}+0.021729 \log \left(\mathrm{x}_{3}\right)^{3}
$$

$$
\begin{array}{llll}
(-0.38) & (0.51) \quad(-0.55) \quad(0.60)
\end{array}
$$

$\mathrm{R}^{2}=0.053, \mathrm{~F}=0.81, \mathrm{DW}=1.955, *=$ significant at $5 \%$ level, $\mathrm{y}_{3}=\mathrm{CO}_{2}$ emission per capita in metric tons of Green land, $\mathrm{x}_{3}=$ GDP per capita in US\$ of Greenland. There is no decoupling from $\mathrm{co}_{2}$ emission per cap$\operatorname{ita}\left(\delta \operatorname{logy}_{3} / \delta \log _{3}\right.$ is greater than one), there is absolute decoupling from square of GDP per cap$\mathrm{ita}\left(\delta \log \mathrm{y}_{3} / \delta \log \left(\mathrm{x}_{3}\right)^{2}\right.$ is less than zero), and there is relative decoupling from cube of GDP per capita of Green$\operatorname{land}\left(\delta \log _{3} / \delta \log \left(\mathrm{x}_{3}\right)^{3}\right.$ is less than one $)$, but all coefficients are not significant at $5 \%$ level.

In Iceland, the same conclusion can be drawn like Greenland.

$$
\log \left(\mathrm{y}_{4}\right)=-15.913+5.2187 \log \left(\mathrm{x}_{4}\right)-0.4956 \log \left(\mathrm{x}_{4}\right)^{2}+0.0152 \log \left(\mathrm{x}_{4}\right)^{3}
$$

$$
(-0.89)(0.93) \quad(-0.84) \quad(0.74)
$$

$\mathrm{R}^{2}=0.31, \mathrm{~F}=6.52^{*}, \mathrm{DW}=0.543, *=$ significant at $5 \%$ level, $\mathrm{y}_{4}=\mathrm{CO}_{2}$ emission per capita in metric ton of Iceland, $\mathrm{x}_{4}=\mathrm{GDP}$ per capita in US $\$$ of Iceland. There is no decoupling from $\mathrm{CO}_{2}$ emission per capita $\left(\delta \log _{4} / \delta \log _{4}\right.$ is greater than one), there is absolute decoupling from square of GDP per capita $\left(\delta \log _{4} / \delta \log \left(\mathrm{x}_{4}\right)^{2}\right.$ is less than zero) and there is relative decoupling from cube of GDP per capita of Iceland $\left(\delta \log _{4} / \delta \log \left(\mathrm{x}_{4}\right)^{3}\right.$ is less than one) but all coefficients are not significant at $5 \%$ level.

In Norway,the Environmental Kuznets Curve is justified through the following estimated equation.

$\log \left(\mathrm{y}_{5}\right)=-45.00646+14.1804 \log \left(\mathrm{x}_{5}\right)-1.4195 \log \left(\mathrm{x}_{5}\right)^{2}+0.04732 \log \left(\mathrm{x}_{5}\right)^{3}$

$$
(-2.108)^{*} \quad(2.17)^{*} \quad(2.145)^{*} \quad(2.129)^{*}
$$

$\mathrm{R}^{2}=0.339, \mathrm{~F}=7.18^{*}, \mathrm{DW}=1.105, *=$ significant at $5 \%$ level, $\mathrm{y}_{5}=\mathrm{CO}_{2}$ emission per capita in metric tons of Norway, $\mathrm{x}_{5}=\mathrm{GDP}$ per capita in US $\$$ of Norway, There is no decoupling from $\mathrm{co}_{2}$ emission per capita $\left(\delta \log _{5} / \delta \log _{5}\right.$ is greater than one), there is absolute decoupling from square of GDP per capita $\left(\delta \log _{5} / \delta \log \left(\mathrm{x}_{5}\right)^{2}\right.$ is less than zero), and there is relative decoupling from cube of GDP per capita of Norway $\left(\delta \log y_{5} / \delta \log \left(\mathrm{x}_{5}\right)^{3}\right.$ is less than one and greater than zero)and all coefficients are significant at $5 \%$ level.Thus,EKC hypothesis is revisited.

In Sweden, the decoupling $\mathrm{CO}_{2}$ emission from the GDP per capita is satisfied from the estimated equation.

$\log \left(\mathrm{y}_{6}\right)=-47.710+15.9049 \log \left(\mathrm{x}_{6}\right)-1.6507 \log \left(\mathrm{x}_{6}\right)^{2}+0.0556 \log \left(\mathrm{x}_{6}\right)^{3}$
$(0.22)$
(1.32)
$(-1.34)$
(1.33) 
$\mathrm{R}^{2}=0.86, \mathrm{~F}=90.74 *, \mathrm{DW}=0.748$, * $=$ significant at $5 \%$ level, $\mathrm{y}_{6}=\mathrm{CO}_{2}$ emission per capita in metric tons of Sweden, $\mathrm{x}_{6}=\mathrm{GDP}$ per capita in US\$ of Sweden, There is no decoupling from $\mathrm{CO}_{2}$ emission per cap$\operatorname{ita}\left(\delta \log _{6} / \delta \log _{6}\right.$ is greater than one), there is absolute decoupling from square of GDP per capita $\left(\delta \log y_{6} / \delta \log \left(\mathrm{x}_{6}\right)^{2}\right.$ is less than zero), and there is relative decoupling from cube of GDP per capita of Sweden $\left(\delta \log y_{6} / \delta \log \left(\mathrm{x}_{6}\right)^{3}\right.$ is less than one and greater than zero), and all coefficients are not significant at $5 \%$ level.

In Nordic countries, growth rates of $\mathrm{CO}_{2}$ emission per capita from 1970-2016 have been declining except in Norway along with the increase in growth rates of GDP per capita which clearly signify the IPCC targets of reducing emissions and convergence of Kuznets hypothesis. These observations have been arranged in Table 1.

Table 1. Growth rates of emission and GDP per capita

\begin{tabular}{|c|c|c|c|c|}
\hline Country & $\begin{array}{c}\text { Growth rate of } \mathrm{CO}_{2} \text { emission } \\
\text { per capita 1970-2016 }\end{array}$ & Significant at 5\% level & $\begin{array}{c}\text { Growth rate of GDP per capita } \\
1970-2016\end{array}$ & $\begin{array}{c}\text { Significant at } \\
5 \% \text { level }\end{array}$ \\
\hline Denmark & -1.12 & yes & 5.74 & yes \\
\hline Finland & 0.09 & no & 5.86 & yes \\
\hline Greenland & 0.16 & no & 6.58 & yes \\
\hline Iceland & -0.45 & yes & 5.64 & yes \\
\hline Norway & 0.48 & yes & 6.69 & yes \\
\hline Sweden & -1.84 & yes & 4.95 & yes \\
\hline
\end{tabular}

Source: calculated by author.

The structural breaks of $\mathrm{CO}_{2}$ emission per capita are showing downwards in the countries e.g. Denmark, Iceland and Sweden and no breaks were visible in Finland and Greenland during 1970-2016.Only Norway is the example of upward structural break of $\mathrm{CO}_{2}$ emission per capita.These findings are shown in the Table 2 .

Table 2. Structural breaks of emissions of Nordic countries

\begin{tabular}{|c|c|c|c|}
\hline $\begin{array}{c}\mathrm{CO}_{2} \text { emission per capita in } \\
\text { metric ton 1970-2016 }\end{array}$ & Structural breaks & Year & Significant at 5\% level \\
\hline Denmark & downward & 2000,2011 & yes \\
\hline Finland & No breaks & & yes \\
\hline Greenland & No breaks & 2008 & yes \\
\hline Iceland & downward & 1978 & yes \\
\hline Norway & upward & $1980,1989,2006$ & \\
\hline Sweden & downward & & \\
\hline
\end{tabular}

Source: calculated by author.

Taking 6 Nordic countries under fixed effect panel least square method with 6 cross sections , 280 observations from 1970 to 2016, the estimate panel regression is found as ,

$$
\log (\mathrm{y})=-37.9566+13.1189 \log (\mathrm{x})-1.40325 \log (\mathrm{x})^{2}+0.04921 \log (\mathrm{x})^{3}
$$

$$
(-2.06)^{*}(2.24)^{*} \quad(-2.28)^{*} \quad(2.309)^{*}
$$

$\mathrm{R}^{2}=0.158, \mathrm{~F}=0.88, \mathrm{DW}=0.34, \mathrm{y}=\mathrm{CO}_{2}$ emission per capita in metric tons of Nordic Countries, $\mathrm{x}=\mathrm{GDP}$ per capita in US\$ of Nordic Countries, $*=$ significant at $5 \%$ level.

The estimate states that there is no decoupling from per capita GDP $(\delta \log y / \delta \log x$ is greater than one), but there is absolute decoupling from square of the per capita GDP $\left(\delta \operatorname{logy} / \delta \log (\mathrm{x})^{2}\right.$ is less than zero $)$ and there is relative decoupling from cube of the per capita GDP of the Nordic Countries $\left(\delta \log y / \delta \log (\mathrm{x})^{3}\right.$ is less than one but greater than zero) from 1970 to 2016 .All the coefficients are significant at 5\% level. It means that the hypothesis of Environmental Kuznets curve is fully satisfied.

Since the assumed function is cubic so it is nonlinear cyclical and the shape the estimated curves are nearly inverse $\mathrm{U}$ shapes. Although its $\mathrm{R}^{2}$ is very low and $\mathrm{F}$ is insignificant and $\mathrm{DW}$ implies autocorrelation, however all $t$ values of the coefficients are significant at $5 \%$ level.

The estimated curve is plotted in Figure 2 below. 


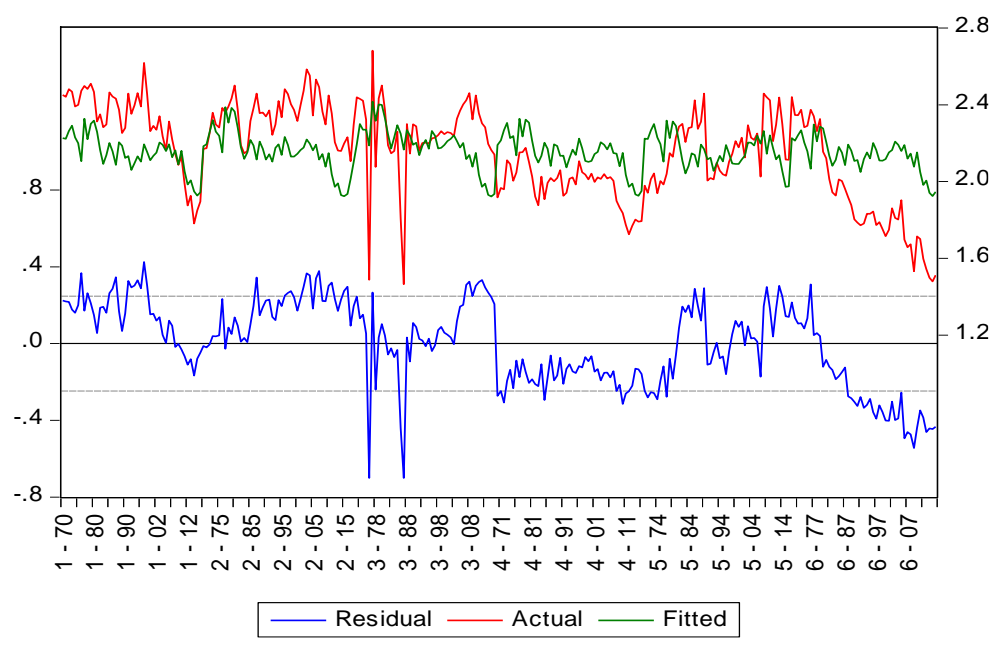

Figure 2. Estimated EKC

Source: plotted by author.

Johansen Fisher Panel cointegration test among $\log (\mathrm{y}), \log (\mathrm{x}), \log (\mathrm{x})^{2}$ and $\log (\mathrm{x})^{3}$ taking first difference series during 1970-2016 assured that there is one cointegrating equation as seen from Trace Statistic and Max Eigen Statistic which are tabulated in Table3 .It states that there is long run association between the per capita $\mathrm{CO}_{2}$ emission and GDP in Nordic countries.

Table 3. Panel Cointegration test

\begin{tabular}{|c|c|c|c|c|}
\hline $\begin{array}{c}\text { Hypothesized } \\
\text { No. of CE(s) }\end{array}$ & $\begin{array}{c}\text { Fisher Stat.* } \\
\text { (from Trace Test) }\end{array}$ & Probability & $\begin{array}{c}\text { Fisher Stat.* } \\
\text { (from Max-Eigen Test) }\end{array}$ & Probability** \\
\hline None & 139.8 & 0.0000 & 154.2 & 0.0000 \\
\hline At most 1 & 20.85 & 0.0527 & 17.04 & 0.1480 \\
\hline At most 2 & 11.24 & 0.5084 & 11.17 & 0.5146 \\
\hline At most 3 & 11.60 & 0.4784 & 11.60 & 0.4784 \\
\hline
\end{tabular}

Notes: * Probabilities are computed using asymptotic Chi-square distribution, **MacKinnon-Haug-Michelis (1999) p-values.

Source: calculated by author.

Since there is panel cointegration among the variables, therefore, the estimated equations of VECM are given below.

[1] $\Delta \log _{\mathrm{t}}=0.000349 \mathrm{EC}-0.5189 \Delta \log \mathrm{y}_{\mathrm{t}-1}-0.190 \Delta \log \mathrm{y}_{\mathrm{t}-2}-17.4146 \Delta \log \mathrm{x}_{\mathrm{t}-1}+19.395 \Delta \log \mathrm{x}_{\mathrm{t}-2}$

$$
(0.24) \quad(-8.36)^{*} \quad(3.03)^{*} \quad(-1.53)
$$

$+1.729 \Delta \log \mathrm{x}_{\mathrm{t}-1-1}^{2}-1.927 \Delta \log \mathrm{x}_{\mathrm{t}-2-2}^{2}-0.0569 \Delta \log \mathrm{x}_{\mathrm{t}-1}^{3}+0.0638 \Delta \log \mathrm{x}_{\mathrm{t}-2-0.0192}^{3}$
(1.51)
$(-1.81)$
$(-1.49)$
(1.78)
$(-1.71)$

$\mathrm{R}^{2}=0.249, \mathrm{~F}=9.21, \mathrm{AIC}=-1.176, \mathrm{SC}=-1.039, *=$ significant at $5 \%$ level

This estimate is a bad fit where coefficient of $\mathrm{EC}$ is positive which implies that there is no long run causality. Although $\Delta \log _{\mathrm{t}}$ is significantly related with $\Delta \log _{\mathrm{t}-1}$ and $\Delta \log _{\mathrm{t}-2}$ negatively.

[2] $\Delta \log \mathrm{x}_{\mathrm{t}}=-0.0028 \mathrm{EC}+0.11028 \Delta \log \mathrm{y}_{\mathrm{t}-1}+0.0528 \Delta \log \mathrm{y}_{\mathrm{t}-2}-11.090 \Delta \log \mathrm{x}_{\mathrm{t}-1}-4.986 \Delta \log \mathrm{x}_{\mathrm{t}-2}$

$$
(-2.56)^{*} \quad(2.31)^{*} \quad(1.09) \quad(-1.27) \quad(-0.62)
$$

$+1.255 \Delta \log x_{t-1}^{2}+0.5020 \Delta \log x_{t-2}^{2}-0.0454 \Delta \log x_{t-1}^{3}-0.0175 \Delta \log x^{3}{ }_{t-2}+0.0556$
(1.43)
$(0.61)$
$(-1.55)$
$(-0.63)$
$(6.46)^{*}$

$\mathrm{R}^{2}=0.278, \mathrm{~F}=10.67, \mathrm{AIC}=-1.703, \mathrm{SC}=-1.565,{ }^{*}=$ significant at $5 \%$ level

It is not a good fit yet the coefficient of EC is negative and significant which implies that it is moving towards equilibrium in the long run where the speed of adjustment is $0.28 \%$ per year. 
And, $\Delta \log x_{t}$ and $\Delta \log y_{t-1}$ are positively related significantly.The fitted and actual lines are shown in the figure 3 where the fitted line merges to zero.

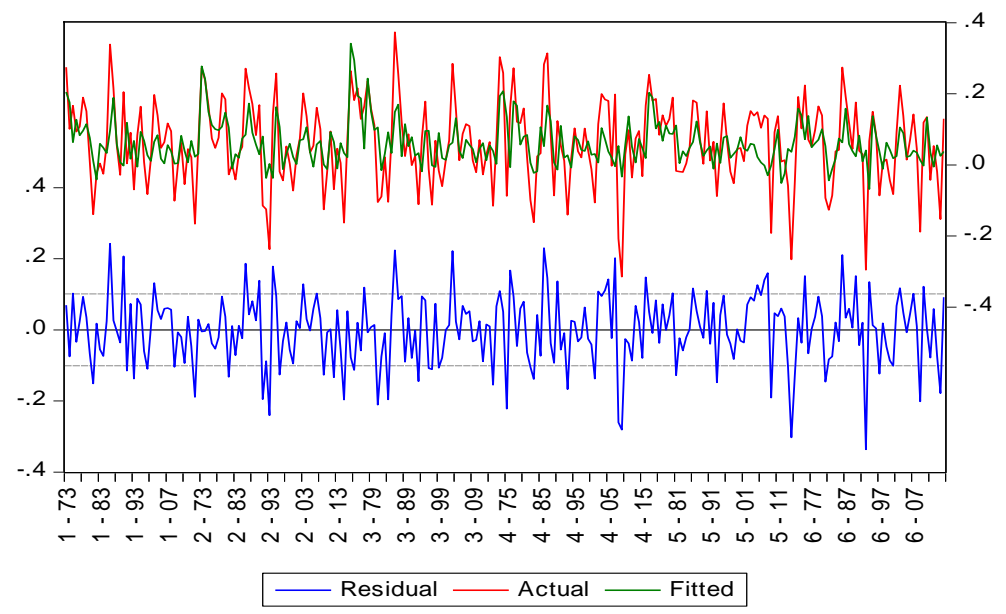

Figure 3. Estimated VECM -2

Source: plotted by author.

[3] $\Delta \log \mathrm{x}^{2}=-0.0477 \mathrm{EC}+2.1489 \Delta \log \mathrm{y}_{\mathrm{t}-1}+1.0971 \Delta \log \mathrm{y}_{\mathrm{t}-2}-231.472 \Delta \log \mathrm{x}_{\mathrm{t}-1}-97.377 \Delta \log \mathrm{x}_{\mathrm{t}-2}$
$(-2.12)^{*}$
$(2.21)^{*}$
$(1.11)$
$(-1.30)$
$(-0.59)$

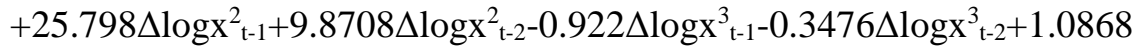

(0.59)

$(-1.55)$

$(-0.62)$

$(6.199)^{*}$

$\mathrm{R}^{2}=0.232, \mathrm{~F}=8.36, \mathrm{AIC}=4.32, \mathrm{SC}=4.45, *=$ significant at $5 \%$ level

Similarly, it is not a good fit yet the coefficient of EC is negative and significant which implies that it is moving towards equilibrium in the long run where the speed of adjustment is $4.77 \%$ per year. And, $\Delta \operatorname{logx}_{t}{ }_{t}$ and $\Delta \operatorname{logy}_{\mathrm{t}-1}$ is positively related significantly. The fitted and actual lines are shown in the figure 4 where the fitted line merges to zero.

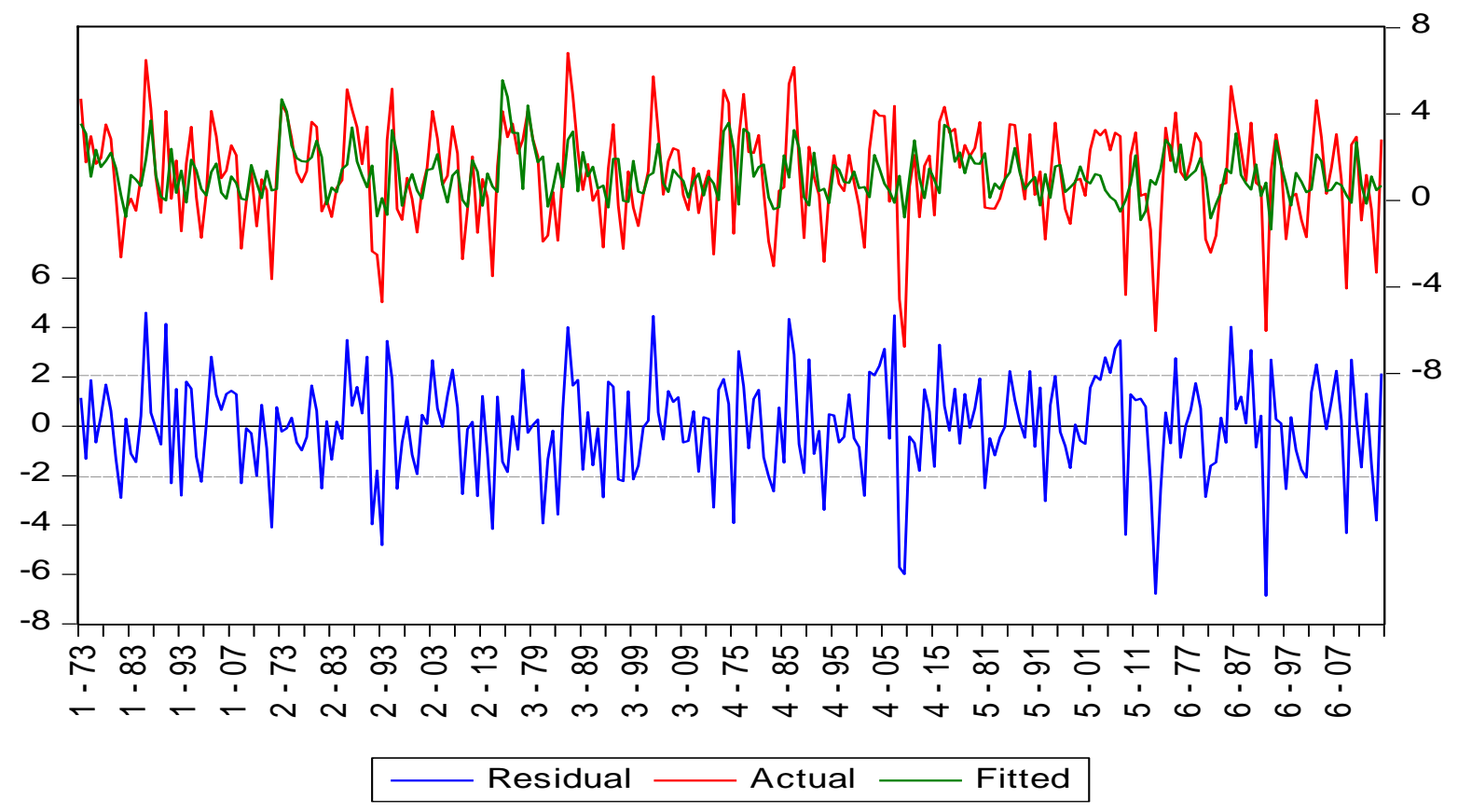

Figure 4. Estimated VECM-3

Source: plotted by author. 
[4] $\Delta \log \mathrm{x}_{\mathrm{t}}^{3}=-0.6142 \mathrm{EC}+31.542 \Delta \log \mathrm{y}_{\mathrm{t}-1}+17.1307 \Delta \log \mathrm{y}_{\mathrm{t}-2}-3604.487 \Delta \log \mathrm{x}_{\mathrm{t}-1}-1468.143 \Delta \log \mathrm{x}_{\mathrm{t}-2}$
$(-1.77)$
$(2.11)^{*}$
(1.13)
$(-1.32)$
$(-0.58)$

$+396.005 \Delta \log x_{t-1}^{2}+149.811 \Delta \log x_{t-2}^{2}-13.996 \Delta \log x_{t-1}^{3}-5.3079 \Delta \log x_{t-2}^{3}+16.0659$
(1.44)
(0.50)
$(-1.52)$
$(-0.61)$
$(5.94)^{*}$

$\mathrm{R}^{2}=0.194, \mathrm{~F}=6.67, \mathrm{AIC}=9.79, \mathrm{SC}=9.92, *=$ significant at $5 \%$ level.

Again,the estimated VECM-4 is not a good fit but coefficient of EC is negative which means that it moves towards equilibrium but it is not significant at $5 \%$ level. Besides, $\Delta \log x^{3}$ and $\Delta \log y_{t-1}$ are positively associated significantly. In the figure 5 , it is found the fitted line insignificantly moves to zero.

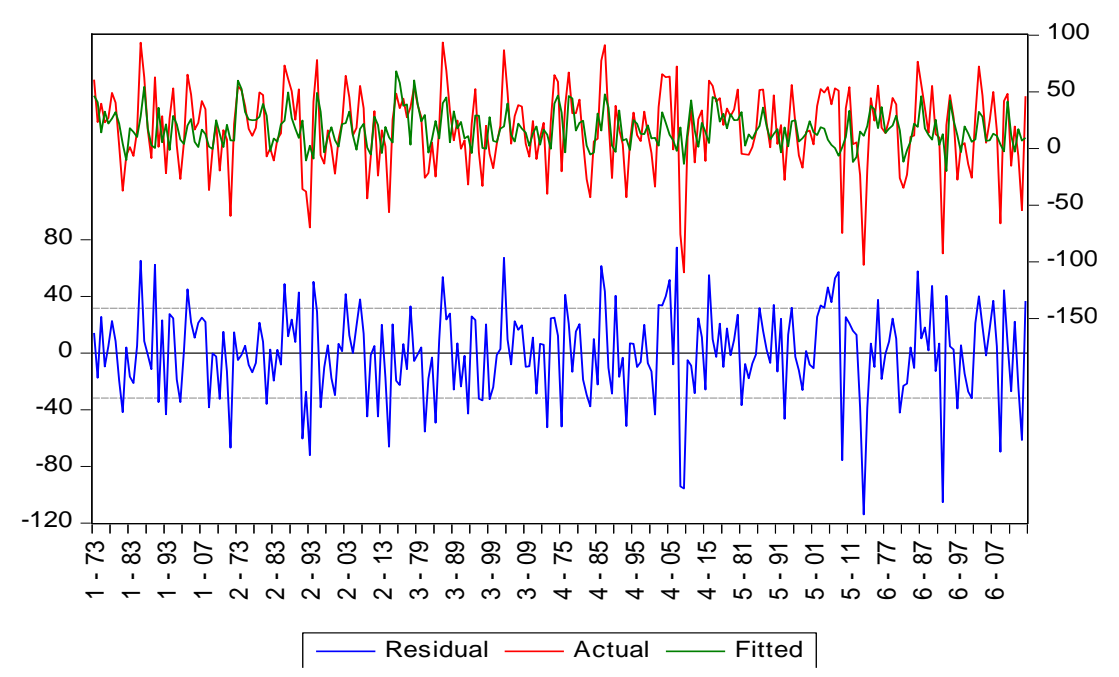

Figure 5. Estimated VECM-4

Source: plotted by author.

From the system equations [1]-[4], it was found four cointegrating equations which are given below,

[1] $\Delta \log \mathrm{y}_{\mathrm{t}}=0.000349 \log \mathrm{y}_{\mathrm{t}-1}+2250.564 \log \mathrm{x}_{\mathrm{t}-1}-216.6682 \log \mathrm{x}_{\mathrm{t}-1}{ }^{2}-6.9350 \mathrm{x}_{\mathrm{t}-1}{ }^{3}-7769.259$
$(0.24)$
$(16.34)^{*}$
$(-25.83)^{*}$
$(15.29)^{*}$

[2] $\Delta \log \mathrm{x}_{\mathrm{t}}=-0.002834 \log \mathrm{y}_{\mathrm{t}-1}+2250.564 \log \mathrm{x}_{\mathrm{t}-1}-216.6682 \log \mathrm{x}_{\mathrm{t}-1}{ }^{2}-6.9350 \mathrm{x}_{\mathrm{t}-1}{ }^{3}-7769.259$
$(-2.56)^{*}$
$(16.34)^{*}$
$(-25.83)^{*}$
$(15.29)^{*}$

[3] $\Delta \log \mathrm{x}_{\mathrm{t}}^{2}=-0.047719 \log \mathrm{y}_{\mathrm{t}-1}+2250.564 \log \mathrm{x}_{\mathrm{t}-1}-216.6682 \log \mathrm{x}_{\mathrm{t}-1}{ }^{2}-6.9350 \mathrm{x}_{\mathrm{t}-1}{ }^{3}-7769.259$

$$
(-2.12)^{*} \quad(16.34)^{*} \quad(-25.83)^{*} \quad(15.29)^{*}
$$

[4] $\Delta \log \mathrm{x}_{\mathrm{t}}{ }^{3}=-0.6138 \log \mathrm{y}_{\mathrm{t}-1}+2250.564 \log \mathrm{x}_{\mathrm{t}}-216.6682 \log \mathrm{x}_{\mathrm{t}-1}{ }^{2}-6.9350 \mathrm{x}_{\mathrm{t}-1}{ }^{3}-7769.259$

$$
(-1.77) \quad(16.34)^{*} \quad(-25.83)^{*} \quad(15.29)^{*}
$$

From the cointegrating equations, the fundamental axioms can be drawn as follows:

1. The cointegrating equations 2 and 3 have been approaching towards equilibrium which means that there are long run causalities from $\log \mathrm{y}_{\mathrm{t}-1}, \log \mathrm{x}_{\mathrm{t}-1}, \log \mathrm{x}_{\mathrm{t}-1}^{2}$ and $\log \mathrm{x}_{\mathrm{t}-1}{ }^{3}$ to $\Delta \log \mathrm{x}_{\mathrm{t}}$ and $\Delta \log \mathrm{x}_{\mathrm{t}}^{2}$ respectively.These were found from the estimated equations from the system equation 2 .

In the VECM it was assumed one cointegrating equation in the model and therefore, the cointegrating equation is plotted in the Figure 6 which is shown below. 


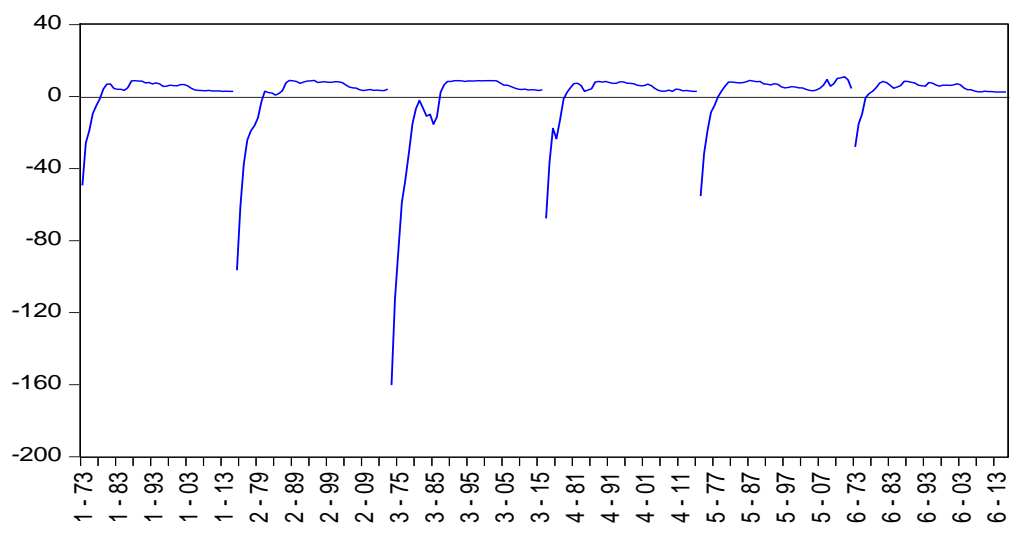

Figure 6. Cointegrating graph

Source: plotted by author.

1. From the Wald test it was found that there are short run causalities from $\Delta \log _{\mathrm{t}-1}$ and $\Delta \log _{\mathrm{t}-2}$ to $\Delta \log _{\mathrm{t}}$. These were estimated from system equation-1.

2. The Wald test showed that there is short run causality from $\Delta \log _{\mathrm{t}-1}$ to $\Delta \log \mathrm{x}_{\mathrm{t}}$ which was estimated from the system equation- 2 .

3. There is short run causality from $\Delta \log \mathrm{y}_{\mathrm{t}-1}$ to $\Delta \log _{\mathrm{t}}^{2}$ which was estimated from the system equation-3 as seen from the Wald test.

4. The Wald test verified that there is short run causality from $\Delta \log y_{t-1}$ to $\Delta \log x_{t}^{3}$ which was estimated from the system equation- 4 .

Now, the Impulse Response Functions in the Figure 7 express that the response of $\log (\mathrm{y})$ to $\log (\mathrm{x}), \log (\mathrm{x})^{2}$ and $\log (\mathrm{x})^{3}$ are significant and converge to zero that is there are causalities from $\log (\mathrm{y})$ to $\log (\mathrm{x}), \log (\mathrm{x})^{2}$ and $\log (\mathrm{x})^{3}$ respectively which are shown in the first row.Moreover,all the other functions are nonstationary which implies VECM is nonstationary.

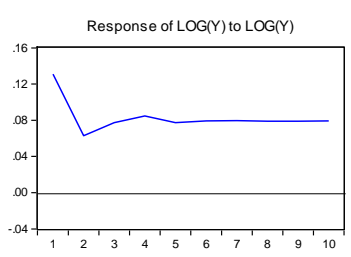

Response to Cholesky One S.D. Innov ations
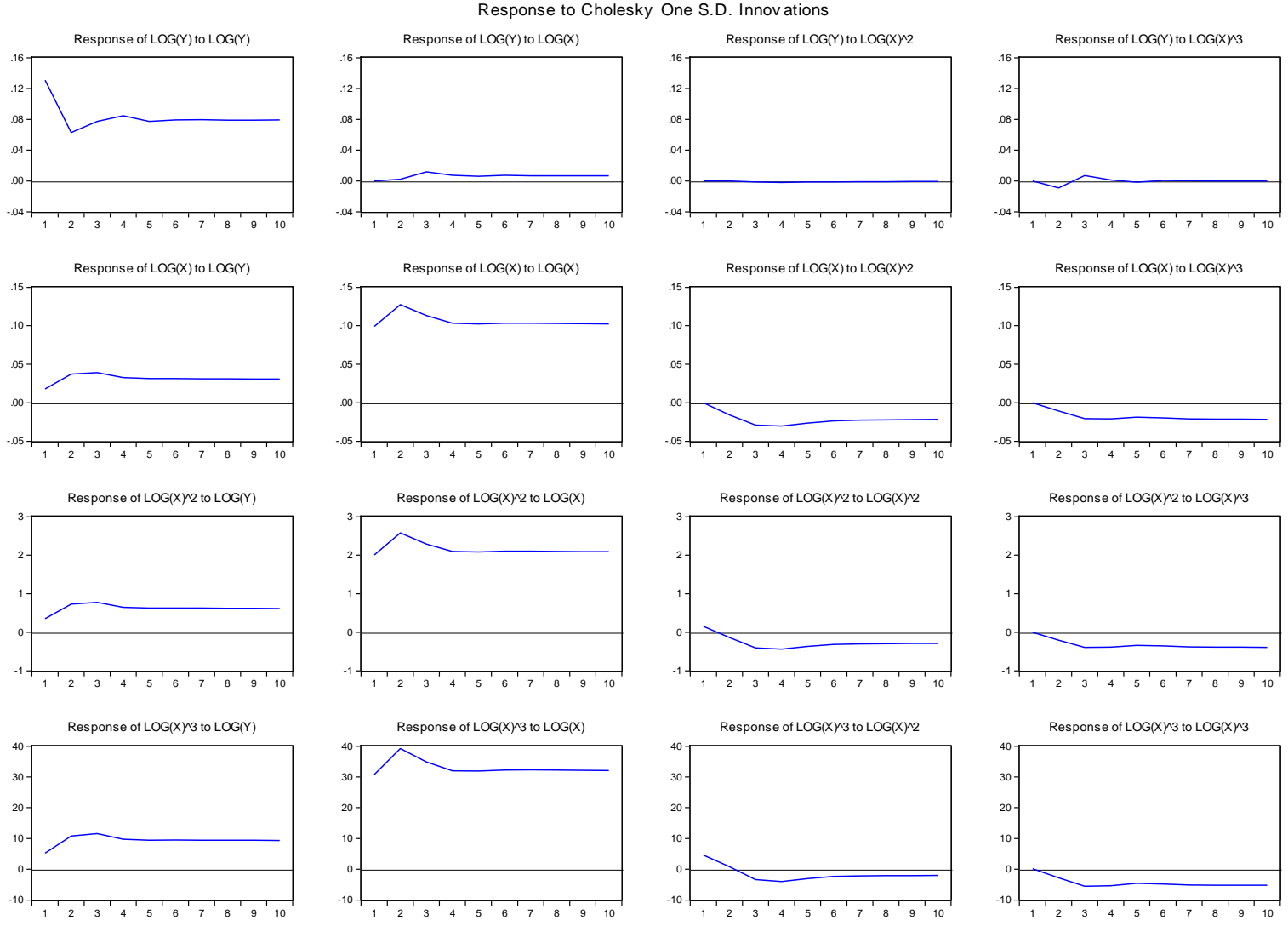

Source: plotted by author.

Figure 7. Impulse Response Functions 
But the VECM is a stable model where all the inverse roots of AR characteristic polynomial lie on or inside the unit circle in which there are 3 unit roots, one root is less than one and others are imaginary which are shown in the Table 4.

Table 4. Values of roots

\begin{tabular}{|c|c|}
\hline Root & Modulus \\
\hline 1.000000 & 1.000000 \\
\hline 1.000000 & 1.000000 \\
\hline 1.000000 & 1.000000 \\
\hline 0.696456 & 0.696456 \\
\hline $0.154710-0.450829 \mathrm{i}$ & 0.476637 \\
\hline$-0.241663-0.379884 \mathrm{i}$ & 0.476637 \\
\hline$-0.241663+0.379884 \mathrm{i}$ & 0.450237 \\
\hline$-0.013559-0.351556 \mathrm{i}$ & 0.450237 \\
\hline $0.200677-0.210618 \mathrm{i}$ & 0.351817 \\
\hline $0.200677+0.210618 \mathrm{i}$ & 0.351817 \\
\hline
\end{tabular}

Source: plotted by author.

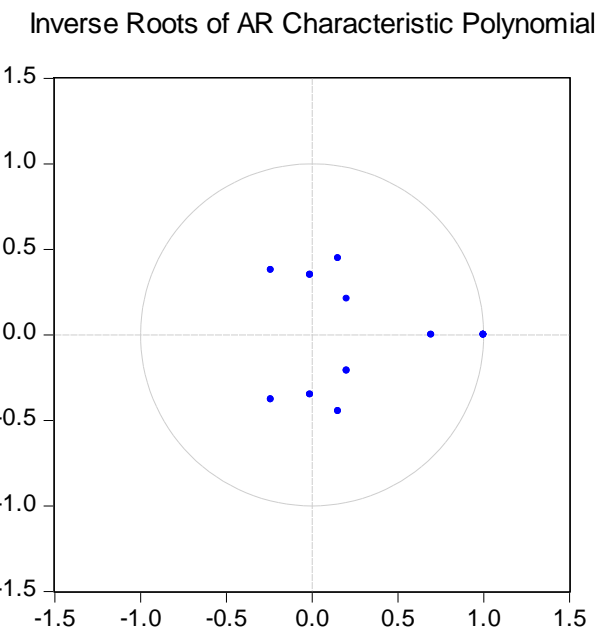

Figure 8. Unit circle

Source: plotted by author.

\section{The Climate Policy of Nordic Countries}

The Nordic Environment Cooperation is led by The Nordic Council of Ministers for the Environment and Climate focusing on implementing the programme for Nordic Cooperation on the Environment and Climate 2019-2024, contributing a long term solution regarding environmental challenges shared by the Nordic countries on five main themes namely,[i] circular economy,[ii]climate change and air quality,[iii]chemicals-environment and health,[iv] bio-diversity and [v]oceans and coastal areas.

The cooperation focuses on value-issues which are [i]exchange of experiences and division of labour,[ii]development of new knowledge,[iii]common solutions and suggestions,[iv] efforts focusing at the EU-and international level.

Their areas of responsibilities are as follows:[i] Nordic Working Group for Circular Economy,[ii] Nordic Working Group for Climate and Air,[iii] Nordic Working Group for chemicals ,environment and health,[iv] Nordic Working Group for bio-diversity,[v] Nordic Working Group for oceans and coastal areas and [vi] Nordic Working Group for environment and economy.

In 2016, Denmark, Finland, Iceland, Norway and Sweden and the US have released a joint statement pledging enhanced cooperation on climate, energy, and the Arctic as well as on economic growth and global development. Even, they will fulfill the Paris Agreement, accelerate the transition to clean energy, enhance adaptation efforts in developing countries, protect and restore forests and continue to take science based steps to protect 
the Arctic and its people. They commit to advocate for the mobilization of private capital to finance the transition to clean energy as well as eliminate investment. At Copenhagen in November, 2016, Denmark, Finland, Norway and Sweden met with UN Environment on environmental dimension of the sustainable development goals and broader global agenda to strengthen U.N. Environment's role. The Nordic expressed that the UN Environment Assembly should provide a platform for stake holders to discuss and find concrete solutions to the most pressing environmental problems. The Nordics also commended U.N. Environment for its efforts to engage with the private sectors and to include the gender aspect in environment work. Priority issues such as oceans and marine litter, ecosystems and bio-diversity, climate change and environmental security and sustainable consumption and production were also discussed. Nordic Council of Ministers had already reduced fossil GHG emissions by 9\% from 1990 to 2011 while GDP had increased by 55\% during the same period where Denmark contributed emission reduction by $18 \%$, Iceland in LULUCF by $26 \%$, but energy use in road transport increased by $23 \%$ by Nordic countries. Sweden reduced GHG emission by $30 \%$.Nordic countries set target for emission reduction from 15 to $40 \%$ within 2020 with average range of $32 \%$. To meet $2^{\circ} \mathrm{C}$ target set by IPCC, an additional reduction of 34\% is required in the period between 2011 and 2020.In 2018 February, Nordic countries released "The Green Bond Market in the Nordics" in Stockholm. It was known that Nordic region issued new bonds at amount of 7.8 billion euros i.e. 10 times higher than 2013. Where Danish deal is 1.25 billion euros .Nordic countries will spend loans to $29 \%$ to renewable energy projects, $20 \%$ in energy efficient buildings and $20 \%$ for low carbon transport. The report estimated that the global market for green bonds could reach 300 billion dollar in 2018 but it needs to increase to at least 1 trillion dollar by 2020 to tackle climate change. The green bond issued by Sweden was amounted to 10.2 billion euros, and Norway, Denmark and Finland issued 2.7 billion euros, 2.3 billion euros and 1.0 billion euros respectively. Sweden committed to reduce $\mathrm{CO}_{2}$ emission by $59 \%$ by 2030 compared to 2005 and targeted to 0 levels within 2045.Norway aims to be carbon neutral by 2030 and Finland targets to reduce by $80 \%$ by 2050 . The leaders also intend to cooperate with international institutions, including international civil aviation organization and the Montreal Protocol on substances that deplete the ozone layer, combating methane emission, restoration and protection of forests and promoting energy for all consistent with the 2030 Agenda for sustainable development.

On $25^{\text {th }}$ January 2019 , Nordic countries signed on a common target to fulfill the following policies within 2020:

a. eliminate all barriers to low emission development and promote transformations towards renewable energy,

b. encourage carbon pricing and fossil fuel subsidy reform,

c. decarbonize the transport sector,

d. emphasize green financing and deploy green procurement, green deals and impact investing,

e. promote joint Nordic business and research consortiums,

f. contribute for further development in carbon capture and storage and bio energy with CCS technologies,

g. maintain or enhance biological carbon sinks and

h. measure carbon sinks with an internationally agreed methodology.(Mead, 2019).

\section{Limitations and future scope of research}

In taking GHG emissions, only $\mathrm{CO}_{2}$ emissions were included but $\mathrm{SO}_{2}$, methane, $\mathrm{CO}$ and other factors were excluded. To justify growth to relate long run relation with decoupling of emissions, the GDP per capita is included while growth rate was not analyzed here. In fixed effect panel regression model, the GDP per capita, the square and cube of GDP per capita of the Nordic countries were taken for analysis which may create debates. But it has huge scope of searching the shapes of Environmental Kuznets Curve.

\section{Conclusions}

The paper concludes that there is no decoupling of $\mathrm{CO}_{2}$ emissions from per capita GDP, but there is absolute decoupling from square of the per capita GDP and there is relative decoupling from cube of the per capita GDP of the Nordic Countries from 1970 to 2016 .All the coefficients are significant at 5\% level. It means that the hypothesis of Environmental Kuznets curve is satisfied. Panel cointegration states that there is long run association among the per capita $\mathrm{CO}_{2}$ emission and GDP in Nordic countries. VECM suggests that there are long run causalities from the emissions per capita to the GDP per capita, square of the GDP per capita and 
cube of GDP per capita respectively in Nordic countries during 1970-2016. Wald test concludes that there is short run causality from the change of emissions per capita to the change of GDP per capita.

\section{References}

1. Aittoniemi (1992). Influences of climate change in the Finnish energy economy.In G. Ostrem (Ed.), Nordisk Hydrologisk Konferens 1992(NHK-92). NH-rapport nr 30. Nordisk Hydrologisk Programm (pp.75-84), Oslo.

2. Alexandersson, H. \& Dahlstrom, B.(1992). Future climate in the Nordic Region. Swedish Meterological and Hydrological Institute, RMK No 64, Nordkoping.

3. Andersson, Julius J. (2015, October). Cars, Carbon Taxes and $\mathrm{CO}_{2}$ Emissions. (Working Paper No 238), Centre for Climate Change Economics and Policy (Working Paper No 212). Grantham Research Institute on Climate Change and Environment. Retrieved from http://www.lse.ac.uk/ GranthamInstitute/wp-content/uploads/2017/03/Working-paper-212-Andersson_update_March 2017.pdf.

4. Atici, C. (2011). Trade liberalization and environmental interaction in Japan and ASEAN:An extended Environmental Kuznets Curve with panel data. Institute of Decoupling Economics - Japan External Trade Organisation. VRF Series No 463.

5. Bai, Jushan, \& Perron, P. (2003). Critical values for Multiple Structural Change Tests. Econometrics Journal, 6, 72-78.

6. Burke, P.J., Shahiduzzaman, M., \& Stern, D.I. (2015). Carbon dioxide emissions in the short run: The rate and sources of economic growth matter. Global Environmental Change, 33, 109-121.

7. Carter, T.R. (1992). The Green House effect and Finnish agriculture. Maatilahallinnon aikakauskirja, 1/1992, Helsinki.

8. Fei, Qin, Rasiah, Rajah \& Shen, Leow Jia(2014, December). The Clean Energy - Growth Nexus with $\mathrm{CO}_{2}$ Emissions and Technological Innovations in Norway and New Zealand. Energy and Environment, 25(8), 1323-1344.

9. Fenger, J., \& Torp, U. (Eds.). (1992). Drivhuseffekt og klimaaeudringer hvad kan det betide for Denmark. Miljoministeriet, Kobenhavn.

10. Fisher, R.A. (1932). Statistical Methods for Research Workers. Edinburg: Oliver \& Boyd. $12^{\text {th }}$ Edition.

11. Grossman, G.M., \& Krueger, A.B. (1991). Environmental impacts of a North American Free Trade Agreement (NBER Working Paper No. 3914). Retrieved from http://www.nber.org/papers/w3914

12. Grossman, G.M., \& Krueger, A.B. (1995).Economic growth and the environment. Quarterly Journal of Economics, 110(2), 353-377.

13. Handrich, Lars, Kemfert, Claudia, Mattes, Anselm, Pavel, Ferdinand, \& Traber, Thure (2015, September). Turning point: Decoupling Green House Gas Emissions from Economic Growth. A Study of DLW ECON. Berlin.

14. Hausman, J.A. (1978, November). Specification Test in Econometrics. Econometrica, 46(6), 1251-1271.

15. Irandoust, Manuchehr (2016). The renewable energy growth nexus with carbon emissions and technological innovation: Evidence from the Nordic countries. Ecological Indicators, 69, 118-125.

16. Johansen, S.(1988). Statistical Analysis of Cointegrating Vectors.bJournal of Economic Dynamics and Control, 12, 231-254.

17. Johansen, S.(1991). Estimation and Hypothesis Testing of Cointegration Vectors in Gaussian Vector Autoregressive Models.Econometrica, 59(6), 1551-1580.

18. Kasperowicz, $\mathrm{Rafal}$ (2015). Economic growth and $\mathrm{CO}_{2}$ emissions:The ECM analysis. Journal of International Studies, 8(3), 91-98.

19. Kulionis, Viktoras (2013, June). The Relationship between renewable energy consumption, $\mathrm{CO}_{2}$ emissions and economic growth in Denmark. (Master Programme in Economic Growth, Lund University, Denmark).

20. Kuznets, Simon (1955, March). Economic growth and Income Inequality. American Economic Review, 49, 1-28.

21. Lin, Boqiang \& Li, Xuehui (2011, September). The effect of Carbon tax on per capita $\mathrm{CO}_{2}$ emissions. Energy Policy, 39(9), 5137-5146.

22. Mackinon, J., Haug, A., \& Michelis, L.(1999). Numerical Distribution Functions of Likelihood Ratio Tests for Cointegration. Applied Econometrics, 14(5), 563-577. 
23. Mazzanti, Massimiliano, \& Musolesi, Antonio (2014, August). Non-linearity, heterogeneity and unobserved effects in the carbon dioxide emissions-economic development relation for advanced countries. (SEEDS Working Paper Series 22/2014). Retrieved from https://ideas.repec.org/p/srt/wpaper/2214.html.

24. Mead, Leila (2019, January 31). Nordic Countries sign Declaration to Accelerate Climate Action towards Carbon Neutrality. Retrieved from http://sdg.iisd.org/news/nordiccountries-sign declaration.

25. Miljoverndepartementel (1991). Drivhu seffekten, virkingerog tiltak, Miljoverndepartementel, Oslo.

26. Obradovic, Sasa, \& Lojanica, Nemanja (2017, April). Energy use, $\mathrm{CO}_{2}$ emissions and economic growth causality in a sample of SEE Countries. Economic Research, 30(1), 511-526.

27. Silva, Susana, Soares, Isabel, \& Pinho, Carlos (2012). The Impact of Renewable Energy Sources on Economic Growth and $\mathrm{CO}_{2}$ emissions - A SVAR approach. European Research Studies, 15, Special Issue on Energy, 133-144.

28. Stern, D. (2004). The Rise and Fall of the Environmental Kuznets curve. World Development, 32(8), $1419-1439$.

29. Urban, Frauke, \& Nordensvard, Johan (2018, August). Low Carbon Energy Transitions in the Nordic Countries: Evidence from the Environmental Kuznets Curve. Energies, 11(9), 2209.

30. Wald, Abraham (1943, November). Test of Statistical Hypothesis concerning several parameters when the number of observations is large. Transactions of American Mathematical Society, 54(3), 426-482.

31. York, R. (2012). Asymmetric effects of economic growth and decline on $\mathrm{CO}_{2}$ emissions. Nature Climate Change, 2, 762-764.

32. Zhao, Siqi (2016). Environmental Kuznets Curve: Evidence from the Nordic Countries 1961-2010. (LUP Student Paper, EKHM 52,20161, Department of Economic History LUND University). Retrieved from https://lup.lub.lu.se/student-papers/search/publication/8892023.

\section{Appendix}

Table A. Nordic countries' GDP per capita and $\mathrm{CO}_{2}$ emission per capita

\begin{tabular}{|c|c|c|c|c|c|c|}
\hline & $\operatorname{Denmark}\left(\mathrm{x}_{1}\right)$ & Finland $\left(\mathrm{x}_{2}\right)$ & Greenland( $\left.\mathrm{x}_{3}\right)$ & Iceland $(\mathrm{x} 4)$ & Norway $(\mathrm{x} 5)$ & Sweden(x6) \\
\hline Year & \multicolumn{6}{|c|}{ GDP per capita in current US\$ } \\
\hline 1970 & 3464.46 & 2467.48 & 1498.28 & 2538.19 & 3306.22 & 4669.44 \\
\hline 1971 & 3845.5 & 2718.21 & 1876.5 & 3203.92 & 3736.35 & 5060.34 \\
\hline 1972 & 4650.31 & 3180.01 & 2196.71 & 3955.37 & 4413.58 & 5942.15 \\
\hline 1973 & 6119.37 & 4176.27 & 2860.28 & 5356.79 & 5689.59 & 7198.27 \\
\hline 1974 & 6770.73 & 5301.54 & 3432.71 & 6936.25 & 6811.53 & 7975.85 \\
\hline 1975 & 7999.12 & 6260.19 & 4257.95 & 6358.56 & 8204.45 & 9974.66 \\
\hline 1976 & 8787.58 & 6744.7 & 4844.67 & 7470.93 & 8927.2 & 10715.04 \\
\hline 1977 & 9783.84 & 7074.36 & 5713.96 & 9809.74 & 10266.12 & 11287.2 \\
\hline 1978 & 11826 & 7634.48 & 7235.55 & 11070.27 & 11462.64 & 12442.58 \\
\hline 1979 & 13752 & 9339.18 & 8480.7 & 12453.38 & 13046.54 & 14667.44 \\
\hline 1980 & 13883.9 & 11232.28 & 9483.77 & 14602.24 & 15772.24 & 16856.76 \\
\hline 1981 & 12081.74 & 10934.57 & 8544.06 & 14913 & 15512.51 & 15366.67 \\
\hline 1982 & 11804.43 & 10945.28 & 7813.69 & 13508.6 & 15224.89 & 13545.26 \\
\hline 1983 & 11857.9 & 10505.83 & 7988.17 & 11498.89 & 14927.52 & 12430.46 \\
\hline 1984 & 11562.91 & 10841.57 & 7198.7 & 11782.37 & 14989.49 & 12914.33 \\
\hline 1985 & 12253.1 & 11405.93 & 7760.83 & 12178.06 & 15753.55 & 13474.16 \\
\hline 1986 & 17201.08 & 14962.26 & 11271.32 & 16163 & 18883.26 & 17727.5 \\
\hline 1987 & 21340.71 & 18580.66 & 14554.39 & 22120.56 & 22505.9 & 21485.29 \\
\hline 1988 & 22527.05 & 22056.7 & 16398.01 & 24089.73 & 24207.28 & 24188.77 \\
\hline 1989 & 21901.06 & 23983.85 & 16813.68 & 22101.99 & 24281.1 & 25300.4 \\
\hline 1990 & 26891.44 & 28380.55 & 18326.81 & 25008.85 & 28242.94 & 30162.32 \\
\hline 1991 & 27011.39 & 25303.22 & 18315.2 & 26405.92 & 28596.93 & 31374.12 \\
\hline
\end{tabular}


Table A (cont.). Nordic countries' GDP per capita and $\mathrm{CO}_{2}$ emission per capita

\begin{tabular}{|c|c|c|c|c|c|c|}
\hline & $\operatorname{Denmark}\left(\mathrm{x}_{1}\right)$ & Finland $\left(\mathrm{x}_{2}\right)$ & Greenland $\left(\mathrm{x}_{3}\right)$ & Iceland $\left(\mathrm{x}_{4}\right)$ & Norway $\left(\mathrm{x}_{5}\right)$ & Sweden $\left(\mathrm{x}_{6}\right)$ \\
\hline Year & \multicolumn{6}{|c|}{ GDP per capita in current US\$ } \\
\hline 1992 & 29569.66 & 22337.49 & 18768.93 & 26722.44 & 30523.99 & 32338.5 \\
\hline 1993 & 27597.97 & 17617.03 & 16797.46 & 23230.47 & 27963.67 & 24080.9 \\
\hline 1994 & 29995.57 & 20305.58 & 18123.96 & 23662.81 & 29315.84 & 25747.24 \\
\hline 1995 & 35351.38 & 26273.47 & 21665.7 & 26239.03 & 34875.2 & 29914.33 \\
\hline 1996 & 35650.72 & 25777.64 & 21422.36 & 27261.17 & 37321.44 & 32587.26 \\
\hline 1997 & 32835.93 & 24676.5 & 19145.56 & 27842.61 & 36628.52 & 29897.79 \\
\hline 1998 & 33368.16 & 25989.41 & 20496.66 & 30847.64 & 34788.78 & 30113.68 \\
\hline 1999 & 33440.8 & 26078.79 & 20170.44 & 32148.15 & 36371.4 & 30577.08 \\
\hline 2000 & 30743.56 & 24253.25 & 19004.11 & 31746.02 & 38146.72 & 29283 \\
\hline 2001 & 30757.65 & 24913.25 & 19275.47 & 28551.79 & 38549.59 & 26969.25 \\
\hline 2002 & 33228.69 & 26834.03 & 20652.88 & 32024.19 & 43061.15 & 29571.7 \\
\hline 2003 & 40458.77 & 32816.16 & 27460.03 & 39086.77 & 50111.65 & 36961.43 \\
\hline 2004 & 46511.61 & 37636.11 & 32070.38 & 46984.07 & 57570.27 & 42442.22 \\
\hline 2005 & 48799.82 & 38969.17 & 32489.78 & 56250.68 & 66775.39 & 43085.35 \\
\hline 2006 & 52026.99 & 41120.68 & 35458.12 & 56121.32 & 74114.7 & 46256.47 \\
\hline 2007 & 58487.05 & 48288.54 & 39780.95 & 68428.35 & 85170.86 & 53324.38 \\
\hline 2008 & 64322.07 & 53401.32 & 44367 & 55632.1 & 97007.94 & 55746.84 \\
\hline 2009 & 58163.29 & 47107.16 & 44918.56 & 40640.99 & 80067.18 & 46207.06 \\
\hline 2010 & 58041.41 & 46202.42 & 43988.33 & 41851.74 & 87770.27 & 52076.26 \\
\hline 2011 & 61753.66 & 50790.72 & 47186.98 & 46181.95 & 100711.2 & 59593.29 \\
\hline 2012 & 58507.5 & 47415.56 & 45936.77 & 44562.82 & 101668.2 & 57134.08 \\
\hline 2013 & 61191.19 & 49638.08 & 47262.28 & 48023.63 & 103059.3 & 60283.25 \\
\hline 2014 & 62548.99 & 49914.62 & 50408.34 & 52855.14 & 97199.92 & 59180.2 \\
\hline 2015 & 53012.99 & 42424.22 & 44912.27 & 51213.66 & 74498.14 & 50812.19 \\
\hline \multirow[t]{2}{*}{2016} & 56307.51 & 45703.33 & 48159.54 & 60529.93 & 70890.36 & 57844.76 \\
\hline & $\operatorname{Denmark}\left(\mathrm{y}_{1}\right)$ & Finland $\left(\mathrm{y}_{2}\right)$ & Greenland $\left(\mathrm{y}_{3}\right)$ & Iceland $\left(\mathrm{y}_{4}\right)$ & Norway $\left(\mathrm{y}_{5}\right)$ & Sweden $\left(\mathrm{y}_{6}\right)$ \\
\hline year & \multicolumn{6}{|c|}{$\mathrm{CO}_{2}$ emission per capita in metric ton } \\
\hline 1970 & 11.6 & 8.77 & 8.22 & 6.8 & 7.23 & 11.48 \\
\hline 1971 & 11.49 & 8.79 & 9.94 & 7.15 & 6.97 & 10.45 \\
\hline 1972 & 11.95 & 9.52 & 11.46 & 7.1 & 7.48 & 10.44 \\
\hline 1973 & 11.8 & 10.58 & 11.37 & 8.26 & 7.71 & 10.74 \\
\hline 1974 & 10.92 & 9.95 & 11.26 & 8.09 & 6.95 & 9.8 \\
\hline 1975 & 11.02 & 9.79 & 10.2 & 7.42 & 7.41 & 9.87 \\
\hline 1976 & 11.86 & 10.85 & 4.43 & 7.75 & 7.28 & 10.74 \\
\hline 1977 & 12.16 & 10.59 & 14.62 & 8.6 & 7.69 & 10.39 \\
\hline 1978 & 11.97 & 10.92 & 7.97 & 8.612 & 8.57 & 9.611 \\
\hline 1979 & 12.31 & 11.4 & 11.4 & 8.81 & 8.41 & 10.24 \\
\hline 1980 & 11.78 & 12.19 & 12.19 & 8.18 & 9.31 & 8.635 \\
\hline 1981 & 10.11 & 10.73 & 10.73 & 7.59 & 9.84 & 8.345 \\
\hline 1982 & 10.49 & 8.93 & 8.93 & 6.84 & 9.98 & 7.482 \\
\hline 1983 & 9.81 & 8.56 & 8.56 & 6.53 & 9.08 & 6.99 \\
\hline 1984 & 9.95 & 8.66 & 8.66 & 7.58 & 9.77 & 6.87 \\
\hline 1985 & 11.75 & 10.13 & 9.58 & 6.74 & 9.81 & 7.47 \\
\hline 1986 & 11.5 & 10.84 & 6.1 & 7.34 & 11.29 & 7.41 \\
\hline 1987 & 11.38 & 11.69 & 4.33 & 7.53 & 9.72 & 7.11 \\
\hline 1988 & 10.74 & 10.55 & 9.97 & 7.4 & 10.09 & 6.81 \\
\hline 1989 & 9.51 & 10.59 & 8.55 & 7.53 & 11.68 & 6.54 \\
\hline 1990 & 9.77 & 10.37 & 9.96 & 7.84 & 7.43 & 6.07 \\
\hline 1991 & 11.69 & 10.71 & 9.85 & 6.86 & 7.53 & 5.97 \\
\hline
\end{tabular}


Table A (cont.). Nordic countries' GDP per capita and $\mathrm{CO}_{2}$ emission per capita

\begin{tabular}{|c|c|c|c|c|c|c|}
\hline & Denmark $\left(\mathrm{y}_{1}\right)$ & Finland $\left(\mathrm{y}_{2}\right)$ & Greenland $\left(\mathrm{y}_{3}\right)$ & Iceland $\left(\mathrm{y}_{4}\right)$ & Norway $\left(\mathrm{y}_{5}\right)$ & Sweden $\left(\mathrm{y}_{6}\right)$ \\
\hline year & \multicolumn{6}{|c|}{$\mathrm{CO}_{2}$ emission per capita in metric ton } \\
\hline 1992 & 10.51 & 9.42 & 8.68 & 6.97 & 7.47 & 5.88 \\
\hline 1993 & 10.99 & 9.95 & 9.04 & 7.5 & 8.15 & 5.94 \\
\hline 1994 & 11.71 & 11.25 & 9.05 & 7.55 & 7.82 & 6.25 \\
\hline 1995 & 10.93 & 10.32 & 9 & 7.28 & 7.67 & 6.25 \\
\hline 1996 & 13.72 & 11.96 & 9.25 & 8.22 & 7.62 & 6.32 \\
\hline 1997 & 11.65 & 11.66 & 9.29 & 7.76 & 8.2 & 5.89 \\
\hline 1998 & 11.227 & 11.06 & 9.41 & 7.66 & 8.53 & 5.98 \\
\hline 1999 & 10.363 & 10.73 & 9.61 & 7.47 & 9.12 & 5.77 \\
\hline 2000 & 9.61 & 10.13 & 9.461 & 7.7 & 8.83 & 5.56 \\
\hline 2001 & 9.87 & 10.99 & 9.56 & 7.37 & 9.29 & 5.75 \\
\hline 2002 & 9.68 & 11.86 & 9.52 & 7.55 & 8.38 & 6.43 \\
\hline 2003 & 10.39 & 13.26 & 9.367 & 7.49 & 9.91 & 6.11 \\
\hline 2004 & 9.36 & 12.83 & 10.25 & 7.68 & 9.29 & 6.06 \\
\hline 2005 & 8.69 & 10.42 & 10.69 & 7.51 & 9.18 & 6.71 \\
\hline 2006 & 10.11 & 12.57 & 11.05 & 7.56 & 9.49 & 5.46 \\
\hline 2007 & 9.2 & 12.09 & 11.28 & 7.42 & 7.58 & 5.25 \\
\hline 2008 & 8.54 & 10.637 & 11.72 & 6.68 & 11.68 & 5.33 \\
\hline 2009 & 8.06 & 9.95 & 10.22 & 6.45 & 11.46 & 4.63 \\
\hline 2010 & 8.41 & 11.58 & 11.58 & 6.27 & 11.29 & 5.55 \\
\hline 2011 & 7.3 & 10.54 & 10.54 & 5.9 & 9.12 & 5.48 \\
\hline 2012 & 6.52 & 9.07 & 10.01 & 5.61 & 9.94 & 4.94 \\
\hline 2013 & 6.86 & 8.68 & 9.8 & 5.87 & 11.45 & 4.68 \\
\hline 2014 & 5.94 & 8.66 & 8.99 & 6.06 & 9.97 & 4.48 \\
\hline 2015 & 6.35 & 9.01 & 8.71 & 6 & 8.29 & 4.39 \\
\hline 2016 & 6.66 & 9.31 & 8.51 & 6.01 & 8.28 & 4.54 \\
\hline
\end{tabular}

Source: World Bank. 